ISSN: 2224-0616

Int. J. Agril. Res. Innov. \& Tech. 7 (2): 36-42, December, 2017 Available online at http://www.ijarit.webs.com

\title{
COMBINATORIAL EFFICACY OF Trichoderma spp. AND Pseudomonas fluorescens TO ENHANCE SUPPRESSION OF CELL WALL DEGRADING ENZYMES PRODUCED BY Fusarium WILT OF Arachis hypogaea. L
}

\author{
P. Rajeswari ${ }^{*}$ and R. Kapoor ${ }^{2}$
}

Received 1 August 2017, Revised 6 October 2017, Accepted 24 December 2017, Published online 31 December 2017

\begin{abstract}
Fusarium oxysporum, the soil borne pathogen causes vascular wilt, on majority of crop plants. It has been demonstrated that two different species of Trichoderma and Pseudomonas fluorescens suppress disease by different mechanisms. Therefore, application of a mixture of these biocontrol agents, and thus of several suppressive mechanisms, may represent a viable control strategy. A necessity for biocontrol by combinations of biocontrol agents can be the compatibility of the co-inoculated micro-organisms. Hence, compatibility between Trichoderma spp. and Pseudomonas fluorescens that have the ability to suppress Fusarium oxysporum in vitro on the activity of pectinolytic enzymes of Fusarium oxysporum. The activity of pectinolytic enzymes, i.e. pectin methyl esterase, endo and exo polymethylgalacturonases and exo and endo pectin trans eliminases produced by Fusarium oxysporum (Control) was higher. Maximum inhibition of pectin methylesterase, exo and endo polymethylgalacturonase and exo and endopectin trans eliminase was shown by culture filtrate of Trichoderma viride + Pseudomonas fluorescens $(\mathrm{Tv}+\mathrm{Pf})(1+2 \%)$, followed by Trichoderma harzianum + Pseudomonas fluorescens, (Th + Pf) $(1.5+2 \%)$ and Trichoderma viride + Trichoderma harzianum $(\mathrm{Tv}+\mathrm{Th})(1+1.5 \%)$. However, pathogenecity suppression of Fusarium oxysporum, a causative of Arachis hypogaea. L by the compatible combination of Trichodema viride + Pseudomonas fluorescens (1+2\%) was significantly better as compared to the single bio-agent. This indicates that specific interactions between biocontrol agents influence suppression of pathogenicity factors directly by combinations of these compatible bio-agents.
\end{abstract}

Keywords: In vitro interactions, Biological control, Fusarium oxysporum, Arachis hypogaea

\footnotetext{
${ }^{1}$ Post-Doctoral Research Fellow, UGC Post-Doctoral Women Fellowship, Department of Botany, University of Delhi, India

${ }^{2}$ Professor, Department of Botany, University of Delhi, Delhi-110007, India

*Corresponding author’s email: aksharaasmitha@gmail.com (P. Rajeswari)
}

\section{Introduction}

Fusarium oxysporum is considered as an important fungus because of its ability to cause wilt disease on wide range of plants. Arachis hypogaea L. (Groundnut) is an important oil seed crop (Brown, 1999) and among diseases of groundnut, Fusarium wilt disease caused by Fusarium oxysporum (Schlecht. Emend. Snyder $\&$ Hansen) is a disease of considerable economic importance in groundnut production. Fusarium oxysporum causing wilt produces several enzymes that act upon the pectic and components of cell wall of host plant. These enzymes are involved in degradation of plant cell components and lignin. Pectic enzymes have been frequently associated with wilt disease on various crops (Cooper and Wood, 1980). Pectic enzymes consist primarily of pectin methyl esterase, polygalacturonase and pectate lyase (Kawano et al., 1999; Verlent et al., 2004). Pectin methyl esterase (PME) catalyzes the removal of methyl groups at C-6 from esterified anhydrogalacturonosyl units in HG and methanol is released and enzyme is active on methyl esters, where there is a free adjacent carboxyl group (Pedrolli et al., 2009). Polygalacturonases catalyze the hydrolysis of $\alpha$ - $(1 \rightarrow 4)$-glycosidic bonds between adjacent non- esterified D-GalpA units in HG, which leads to substrate depolymerization and viscosity reduction. Mechanism of depolymerisation could be differentiated into two enzymes: endo-PG and exo-PG. Endopolygalacturonase (endo-PG) with a random action and exopolygalacturonase (exoPG) with a successive action have been reported by earlier studies. Fungal endo-PGs bind to 4 till 5 adjacent $\alpha$-D-GalpA units from the main chain and hydrolyze between the last two residues at the reducing end (Prade et al., 1999). Exo-PGs attack at the non-reducing end and monomers or dimers are cleaved (Benen and Visser, 2003). Transeliminases (Pectate lyase) catalyze the nonhydrolytic depolymerization of HG chains by $\alpha$ - 
$(1 \rightarrow 4)$-glycosidic bonds breakage between adjacent $\alpha$-D-GalpA monomers, and as a result a double unsaturated $\Delta-(4 \rightarrow 5)$ bond is formed at the non- reducing end. Production of cell wall degrading enzymes (CWDEs) polygalacturonase (PG), pectate lyase (PL), and xylanase was studied in chickpea wilt and the result have implications for the role played by CWDEs in the early and later stages of pathogenesis in chickpea fusarium wilt (J orge et al., 2006). Akrami et al. (2011) demonstrated the ability of Trichoderma harzianum and Trichoderma asperellum isolates and their combination reduced fusarium rot disease and increased dry weight in lentil plants. Pushpavathi et al. (2015) observed that sucker treatment before planting with biocontrol agents Trichodema viride and Pseudomonas fluorescens and soil drenching with the same biocontrol agents twice as booster reduced the Fusarium wilt disease in banana and incidence thereby increasing the yield. Hoda et al. (2016) reported that combinations of Pseudomonas fluorescens (Pf2), Bacillus subtilis (Bs3) and Rahnella aquatilis (Ra39) is beneficial in controlling black leg rot of potato caused by Pectobacterium atrosepticum. There seems to be no report available on the control of Fusarium wilt with the combinations of biocontrol agents on Arachis hypogaea L. The present study was taken whether specific interactions between Trichoderma spp. and Pseudomonas fluorescens influence pathogenicity suppression by combinations of these two phylogeneically unrelated biocontrol agents on Arachis hypogaea L. as compared to single biocontrol agent.

\section{Materials and Methods}

Trichoderma viride, Trichoderma harzianum, Pseudomonas fluorescens and Fusarium oxysporum were obtained from Institute of Microbial Technology (IMTECH, Chandigarh, MTCC Nos 2047,3112,664.2087, respectively) Fusarium oxysporum was grown on Potato Sucrose Agar for 30 days and further grown in Czapek s medium for 7 days and filtrate was taken. Trichoderma viride and Trichoderma harzianum were grown on Malt Extract agar and Pseudomonas fluorescens on Antartic Biotic Medium and grown on Czapek-Dox medium in conical flask. It was further centrifuged and culture filtrate was taken.

\section{In vitro study}

Conidial germination studies were carried out incavity slides by incubating in a moist chamber at room temperature. Conidial suspension of Fusarium oxysporum 8000-12000/ml was prepared, in sterile distilled water with the help of haemocytometer. $1 \mathrm{ml}$ of conidial suspension was added in the cavity slides with each of six concentrations of culture filtrates of three biocontrol agents. For control, conidial suspension was maintained in the sterile distilled water. Slides in triplicates were maintained for each concentration. The slides were incubated in moist chamber at $30^{\circ} \mathrm{C}$ and conidial germination was observed after $24 \mathrm{~h}$. The percentage of inhibition over control was calculated by the formula of Vincent (1927).

$$
\begin{aligned}
& \mathrm{I}=\mathrm{C}-\mathrm{T} \div \mathrm{C} \times 100 \\
& \text { Where, } \\
& \mathrm{I}=\text { Inhibition over control } \\
& \mathrm{C}=\% \text { germination in control } \\
& \mathrm{T}=\% \text { of germination in treated }
\end{aligned}
$$

\section{Poisoned Plate Technique}

The radial growth of the mycelium of $F$. oxysporum was measured by poisoned plate technique. After the sterilization of petriplates $(9 \mathrm{~cm})$, PSA medium, corkborers and other glass wares in an autoclave at $121.5^{\circ} \mathrm{C}$ for $15 \mathrm{~min}$ with $15 \mathrm{lb} / \mathrm{inch}^{2}$ pressure, the prepared culture filtrates of the biocontrol agents (7th day old culture) in six concentrations were added through a Seitz filter to the warm PSA medium separately. The plates were inoculated by placing $9 \mathrm{~mm}$ discs cut from the growing tip of 7 days old culture plates of F. oxysporum. All this was done under laminar flow chamber. PSA plates without any biocontrol agent served as control. The control and treated plates were maintained in triplicates. The inoculated plates were sealed with para film and incubated in BOD incubator at $28^{\circ} \pm 0.2 \mathrm{C}$. The radial growth of the pathogen was measured in $\mathrm{cm}$ along the radial line of the mycelial growth in the petri plates after 7 days of treatment. The optimum inhibitory concentration of different biocontrol agents was determined based on the results of conidial germination and mycelial growth.

\section{Enzyme production}

Czapek-Dox broth supplemented with pectin as carbon source replacing sucrose was used. To 50 $\mathrm{ml}$ sterilized Czapek -Dox broth, the culture filtrate of Tv+Pf (1+2\%), Th+Pf (1.5+2\%) Tv+Th $(1+1.5 \%)$ in their OIC (Optimum Inhibitory Concentration) were amended to the media separately. The disc of $9 \mathrm{~mm}$ was cut and were inoculated in each flask and incubated in the BOD incubator at $28 \pm 2^{\circ} \mathrm{C}$ for 7 days. The control (with pathogen) and treated flasks ( $\mathrm{Tv}+\mathrm{Pf}$, $\mathrm{Th}+\mathrm{Pf}$, $\mathrm{Tv}+\mathrm{Th}$ ) were all maintained in triplicates. After incubation, the fungal mat and the liquid media were separated by double layered Whatman No. 1 filter paper. The filtrates were further centrifuged in a high speed, at 5,000 rpm for $10 \mathrm{~min}$ and the supernatant was used as the enzyme source. 


\section{Assay of pectin methyl esterase (PME) activity}

The enzyme activity was done according to the method of Muse et al. (1972).

\section{Assay of endo polygalacturonase (endoPG) activity}

The activity of endo (PG) was assayed as per the method described by Mahadevan and Sridhar (1986) and the enzyme activity was calculated as

$$
\mathrm{V}=\frac{\mathrm{T}_{0}-\mathrm{T}_{1}}{-\mathrm{T}_{0}-\mathrm{T}_{\mathrm{W}}} \times 100
$$

Where,

$\mathrm{V}=$ percent loss in viscosity.

$\mathrm{T}_{\mathrm{o}}=$ flow time of reaction mixture at 0 minute.

$\mathrm{T}_{1}=$ flow time of reaction mixture at a particular time interval.

$\mathrm{T}_{\mathrm{w}}=$ flow time of distilled water.

\section{Assay of exo polygalacturonase (exoPG) activity}

The activity of exo-PMG was estimated as per the method described by Mahadevan and Sridhar (1986) and was assayed by measuring the monomeric galacturonic acids released by the enzyme by catalysing the pectin degradation. The results were expressed as specific activity units (SAU). From the three-hour incubated reaction mixture, $2.0 \mathrm{ml}$ aliquots were taken and $2 \mathrm{ml}$ of DNS reagent was added and then heated in boiling water bath for $10 \mathrm{~min}$. Then cooled and diluted with $10 \mathrm{ml}$ of distilled water. The orange red colour was read at $575 \mathrm{~nm}$. Control was maintained with boiled enzyme reaction mixture.

\section{Assay of endo and exo pectin trans eliminase (endo and exo PTE) activity}

The activity of the endo (PTE) was estimated by the viscometric method as described by (Mahadevan and Sridhar, 1986) and exo by determining the production of TBA reacting substances.

\section{Statistical analysis}

The statistical analysis of the experimental data was carried out according to ANOVA and significance within the column with Tukey HSD multiple range test (TMRT) at 5\% level of significance $(n=3)$.

\section{Results}

The highest PME activity was recorded in enzyme source of control by specific activity unit (89.25 SAU). The lowest rate of enzyme activity was observed in Tv+Pf treated enzyme source (17.16 SAU) followed by those treated Th+ Pf (21.97 $\mathrm{SAU}$ ) and $\mathrm{Tv}+\mathrm{Th}$ (22.52 SAU). Maximum inhibition of enzyme activity was recorded in $\mathrm{Tv}+\mathrm{Pf}$ treated culture $(80.77 \%)$ followed by Th+Pf (75.38\%) and Tv+Th (74.76 \%) (Fig. 1).

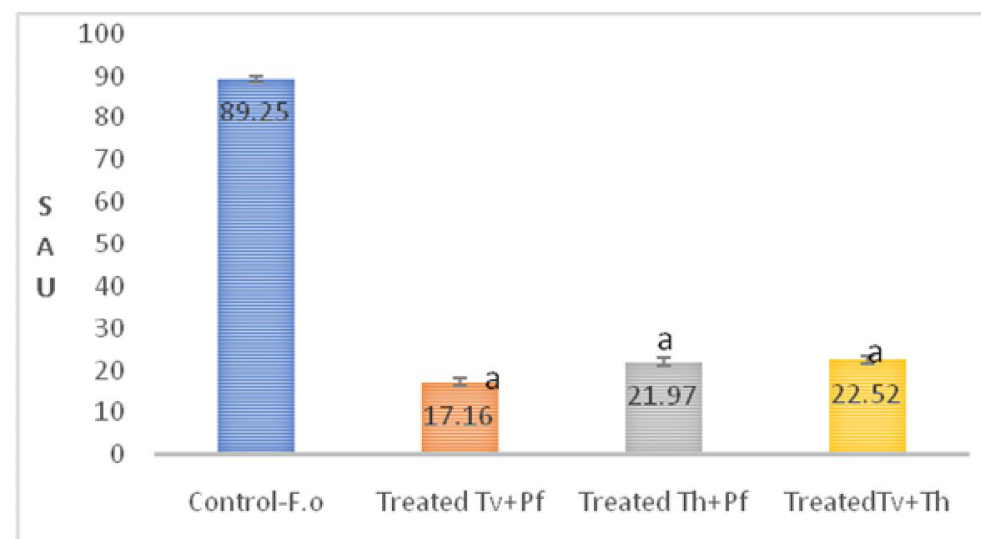

Fig.1 Effect of culture filtrates of Trichoderma viride + Pseudomonas fluorescens (Tv + Pf), Trichoderma harzianum + Pseudomonas fluorescens $(\mathrm{Th}+\mathrm{Pf})$, Trichoderma viride+ Trichoderma harzianum (Tv+Th) on the activity of polymethyl esterase of Fusarium oxysporum in vitro.

ap $<0.001$ as compared to control $S A U=\mu \mathrm{ml}$ of $0.02 \mathrm{~N} \mathrm{NaOH}$ required to maintain $\mathrm{pH} 7 / \mathrm{h}$.

The values within a column followed by different letters are significantly different according to Tukey's HSD multiple range test (TMRT) at $5 \%$ level of significanœ $(n=3)$.

The endo- PMG of control reduced the viscosity Tv+Pf (10.52\% viscosity loss at $180 \mathrm{~min})$ followed of the substrate to $80 \%$ at $180 \mathrm{~min}$. The least by those of Th+Pf (19.04\%) and Tv+Th $26.66 \%)$. endo-PMG activity was observed in the enzyme source obtained from the culture treated with (Fig. 2). 


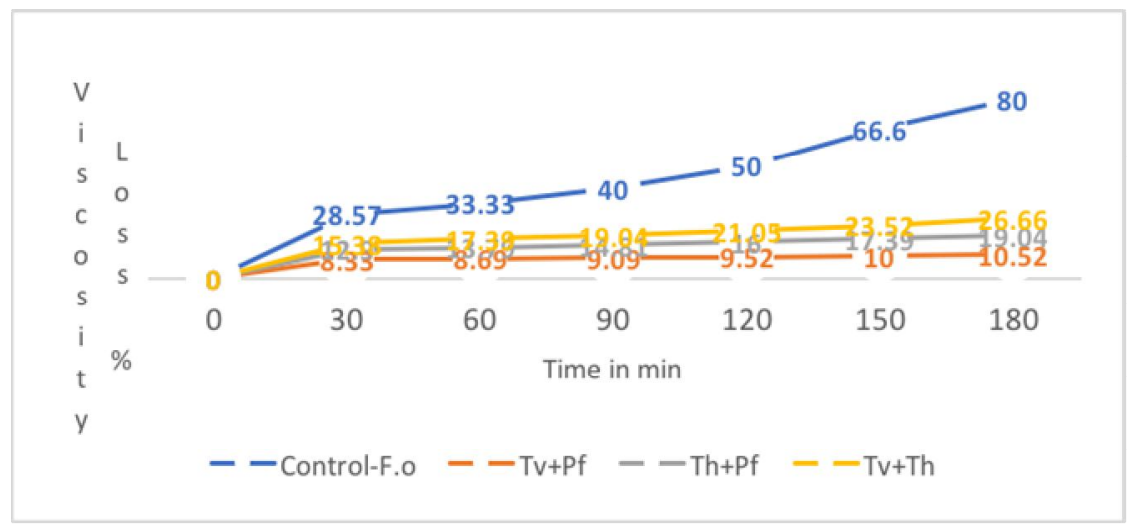

Fig.2. Effect of culture filtrates of Trichoderma viride + Pseudomonas fluorescens $(\mathrm{Tv}+\mathrm{Pf})$, Trichoderma harzianum + Pseudomonas fluorescens $(\mathrm{Th}+\mathrm{Pf})$, Trichoderma viride+ Trichoderma harzianum $(\mathrm{Tv}+\mathrm{Th})$ on the activity of Endo polymethylgalacturonase of Fusarium oxysporum in vitro.

Higher amount of monogalacturonic units was Among the treatments the least amount of sugar released in the case of enzyme source obtained from the control (507.33 SAU), followed by those of Tv+Th (226.54 SAU) and Th+Pf (170.55 SAU). (Fig. 3). was liberated in the case of enzyme source obtained from treatment Tv+Pf (91.00 SAU).

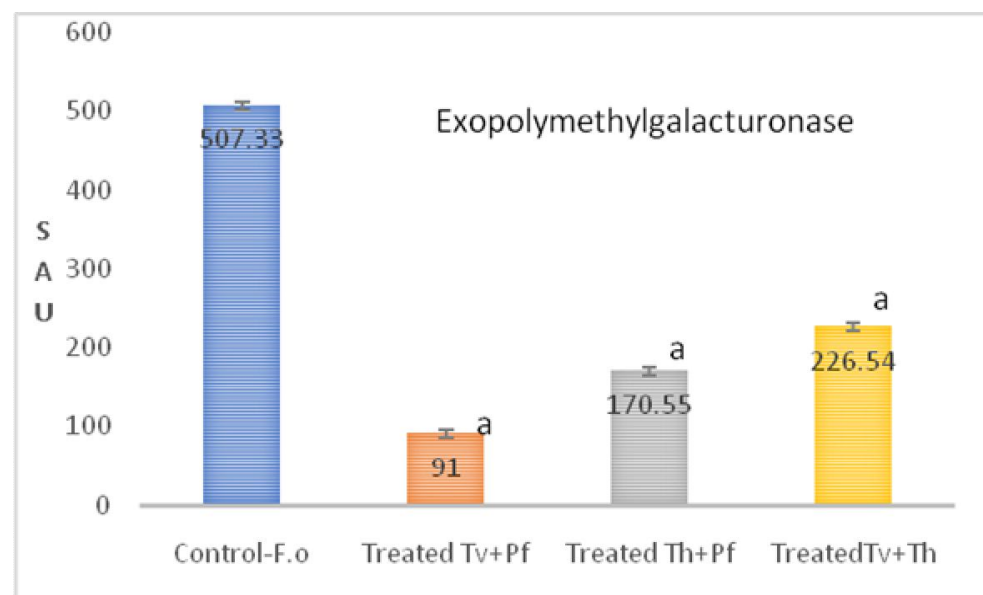

Fig.3 Effect of culture filtrates of Trichoderma viride + Pseudomonas fluorescens $(\mathrm{Tv}+\mathrm{Pf})$, Trichoderma harzianum + Pseudomonas fluorescens (Th + Pf), Trichoderma viride+ Trichoderma harzianum (Tv+ Th) on the activity of Exo polymethylgalacturonase of Fusarium oxysporum in vitro ap $<0.001$ as compared to control

The endo- PTE of control reduced the viscosity of $\mathrm{Tv}+\mathrm{Pf}$ (14.28 \%viscosity loss at180 min) followed the substrate to $66.66 \%$ at $180 \mathrm{~min}$. The least endo- PTE activity was observed in the enzyme by those of Th+Pf (17.39\%) and Tv+Th (23.52\%) source obtained from the culture treated with at 180 min. (Fig. 4) 


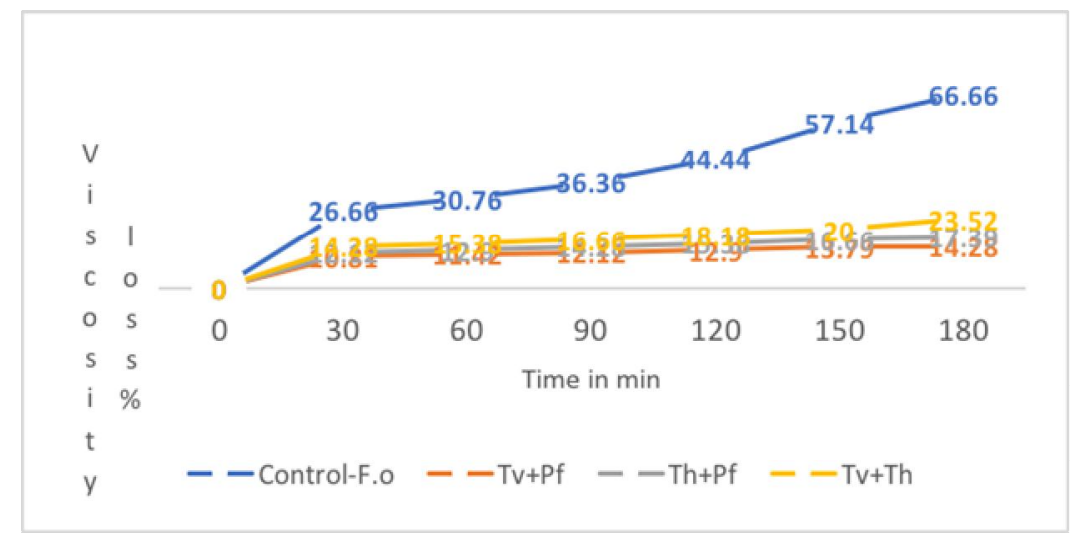

Fig. 4. Effect of culture filtrates of T. viride $+\mathrm{P}$. fluorescens $(\mathrm{Tv}+\mathrm{Pf})$, $\mathrm{T}$. harzianum $+\mathrm{P}$. fluorescens $(\mathrm{Th}+\mathrm{Pf}), \mathrm{T}$. viride+ $\mathrm{T}$. harzianum $(\mathrm{Tv}+\mathrm{Th})$ on the activity of endopectintranseliminases of Fusarium oxysporum in vitro

The activity of exo-PTE was expressed in specific (47.71 SAU). Maximum inhibition of enzyme activity units (SAU). Higher amount of (9.96 SAU) followed by those of T. harzianum+ monogalacturonic units was released in the case P. fluorescens (17.22 SAU) and T. viride $+\mathrm{T}$. of enzyme source obtained from the control harzianum(29.04 SAU). (Fig. 5)

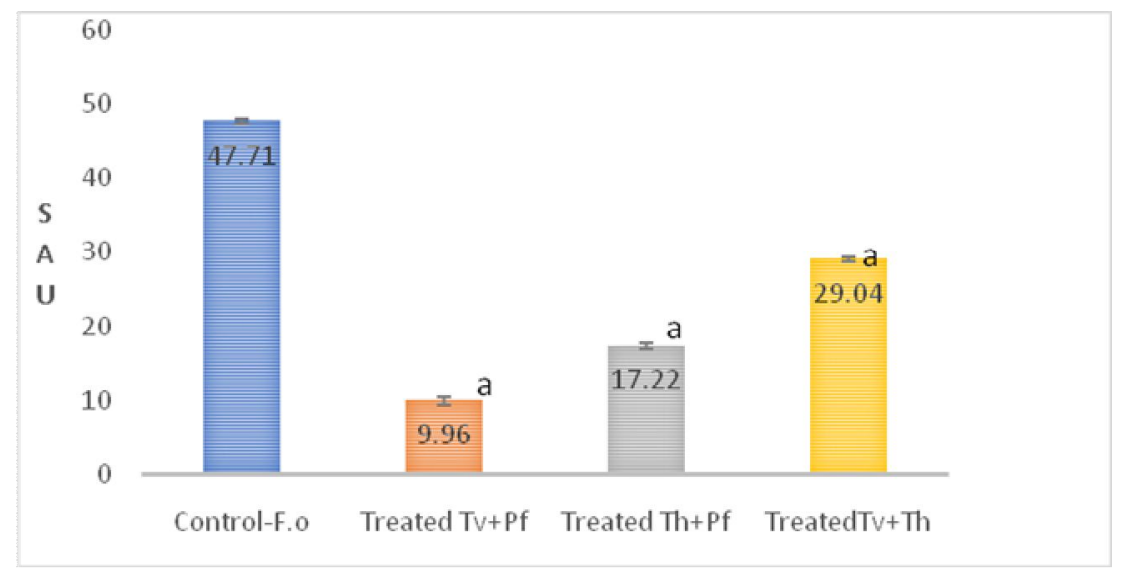

Fig. 5. Effect of culture filtrates of Trichoderma viride + Pseudomonas fluorescens $(\mathrm{Tv}+\mathrm{Pf})$, Trichoderma harzianum + Pseudomonas fluorescens (Th + Pf), Trichoderma viride+ Trichoderma harzianum ( $\mathrm{Tv}+\mathrm{Th}$ ) on the activity of Exo pectin transeliminases of Fusarium oxysporum in vitro

ap $<0.001$ as compared to control $\quad \mathrm{SAU}=$ change in the absorbance at $547 \mathrm{~nm}$ of $0.001 / \mathrm{h}$.

The values within a column followed by different letters are significantly different according to Tukey s HSD multiple range test (TMRT) at 5\% level of significance $(n=3)$

\section{Discussion}

In the present study, the results show the highest Poly methyl galacturonase, polygalacturonase, pectin transeliminase activity was observed in enzyme source of control. Waggoner et al. (1955) reported that increased level of PME in diseased plants is due to the enzyme produced by the pathogen and not increased production of PME by the host in response to pathogen. Shukla and Dwivedi (2012) demonstrated that polygalacturonase, pectinmethylesterase, and Cellulose enzymes play an important role in inducing pathogenesis and the enzyme activity was increased in Fusarium sp. causing wilt in pigeon pea which determines higher pathogenicity in comparison to Fusarium oxysporum f.sp. ciceri causing wilt in chickpea.

Maximum inhibition of Pectin methyl galacturonase, polygalacturonase and pectin transeliminase enzyme activity was recorded in Tv+Pf (Trichoderma viride + Pseudomonas fluorescens) treated culture. Our results are in agreement with the earlier studies reported by (Manjula et al., 2004) that the combined application Pseudomonas fluorescens and Trichoderma viride has improved the biocontrol activity against stem rot in groundnut. 
Combination of biocontrol agents with different mechanisms of disease control will have an additive effect and results in enhanced disease control compared to their individual application (Guetsky et al., 2002). The same is reported by (Lehar et al., 2016) stating that administration of biological agents of $\mathrm{T}$. viride combined with $\mathrm{P}$. fluorescens and Streptomyces sp. produce growth hormone or PGPR which stimulates better plant growth and thereby increasing yield in potato and ability to control disease caused by Phytophthora infenstans and Ralstonia solanacearum. Also, our results indicated that inhibition of PME, PG, PTE was recorded in Th+Pf (Trichoderma harzianum+ Pseudomonas fluorescens) treated culture. Our results are in confirmation with the reports of several workers (Lutz et al., 2004) who reported that the use of bacteria and fungi singly or in combination is a promising approach to improve efficacy of biocontrol treatments. This could be attributed to the involvement of different mechanisms in disease suppression like mycoparasitism, antibiosis or competition for place and nutrients. Pyrones such as 6-pentyl pyrone (produced by $\mathrm{T}$. atroviride and $\mathrm{T}$. harzianum) have antifungal activity against various pathogens including Fusarium oxysporum and Bipolaris (Reithner et al., 2005; Mathivanan et al., 2008; Rubio et al., 2009). Glick (2015) demonstrated that inhibition of fungal pathogens by Pseudomonas spp., could be exerted by several mechanisms including production of antibiotics, (2, 4 diacetylphloroglucinol, fengycin, herbicolin, pyoluteorin, Phenazine-1-carboxylic acid, amphisin) HCN, siderophores, volatile compounds and competition for nutrients. Results revealed that inhibition of PME, PG, PTE was recorded in Trichoderma viride + Trichoderma harzianum ( $\mathrm{Tv}+\mathrm{Th})$ treated culture. Our results also support the earlier findings of Khan et al. (2004). Trichoderma harzianum and Trichoderma viride are active rhizosphere colonizers and fungi produce antibiotics such as gliotoxin, viridian, cell wall degrading enzymes and biologically active heat stable metabolites such as ethyl acetate which are involved in disease suppression and plant growth promotion.

\section{Conclusion}

Pathogenicity suppression of Fusarium oxysporum a causative of Arachis hypogaea. L by the compatible combination of Trichodema viride + Pseudomonas fluorescens (1+2\%) was significantly better as compared to other two combinations. This enhanced cell wall degrading enzyme suppression by the combination of bioagents could be the possible mechanisms viz., Production of antibiotics, volatile compounds, and competition for nutrients. The present study concluded that specific interactions between biocontrol agents could influence reduction of pathogenic virulence, which may leads to disease suppression by combinations of these bioagents.

\section{Acknowledgements}

We are thankful to UGC University Grant Commission (India) for funding and to pursue the research under the category of Post-Doctoral Fellowship for Women.

\section{References}

Akrami, M., Golzary, H. and Ahmadzadeh, M. 2011. Evaluations of different combinations of Trichoderma species for controlling Fusarium rot of lentil. African J. Biotech. 10(4): 2653-2658.

Benen, J.A.E. and Visser, J. 2003. Polygalacturonases. pp. 857-866. In: Whitaker, J.R., Voragen, A.G.J., Wong, D.W.S. (eds), Handbook of Food Enzymol. Marcel Dekker Publishi, New York.

Brown, R.G. 1999. Diseases of cereal crops and annual oil seed crops. pp. 297-331. In: Brown, R.G. (Ed) Plant Diseases and their Control, Sarup and Sons, New Delhi.

Cooper, R.M. and Wood, R.K.S. 1980. Cell wall degrading enzymes of vascular wilt fungi. III. Possible involvement of endo-pectin lyase in Verticillium wilt of tomato. Physiol. Plant Path. 16: 285-300.

Glick, B.R. 2015. Biocontrol mechanisms. pp: 123-157. In: Beneficial Plant-Bacterial Interactions. Springer International Publishing, Switzerland.

Guetsky, R., Stienberg, D., Elad, Y., Fischer, E. and Dinoor, A. 2002. Improving biological control by combining biocontrol agents each with several mechanisms of disease suppression. Phytopath. 92: 976-985.

Hoda, H., El-Hendaway, Kamal, A. and Abou Elyousr, M. 2016. Combination of Different antagonistic bacteria to control of potato black leg disease caused by Pectobacterium atrosepticum under greenhouse and field conditions. Int. J. Phytopath. 5: 35-43.

Jorge, I., Navas-Cortés, J .A., Jiménez-Diaz, R.M. and Tena, M'. 2006. Cell wall degrading enzymes in fusarium wilt of chickpea: correlation between pectinase and xylanase activities and disease development in plants infected with two pathogenic races of Fusarium oxysporum f.sp. ciceris. Canadian J. Bot. 84: 1395- 1404.

Kawano, C.Y., Chellegatti, M.A.S.C., Said, S. and Fonseca, M.J.V. 1999. Comparative study of intracellular and extracellular pectinases produced by P. frequentans. Biotech. Appl. Biochem. 29: 133-140. 
Khan, M.R., Khan, S.M. and Mohiddin, F.A. 2004. Biological control of Fusarium wilt of chickpea through seed treatment with the commercial formulation of Trichoderma harzianum and/or Pseudomonas fluorescens. Phytopath. Mediterr. 43: 2025.

Lehar, L., Wardiyati, T. and Maghgoer, M.D. 2016. Selection of potato varieties. (S. tuberosum L.) in midlands and the effect of using biological agents. Int. J . Biosci. 9: 129138.

Lutz, M.P., Wenger, S., Maurhofer, M., De fago, G. and Duffy, B. 2004. Signaling between bacterial and fungal biocontrol agents in a strain mixture. FEMS Microl. Ecol. 48: 447455.

Mahadevan, A. and Sridhar, R. 1986. Methods in physiological plant pathology (3rd ed.) Sivakami Publications, Madras, India. pp. 183-184.

Manjula, K., Krishna Kishore, G., Giris, A.G. and Singh, S.D. 2004. Combined application of Pseudomonas fluorescens and Trichoderma viride has an improved biocontrol activity against stem rot in groundnut. Plant Path. J . 20(1): 75-80.

Mathivanan, N., Prabavathy, V.R. and Vijayanandraj, V.R. 2008. The effect of fungal secondary metabolites on bacterial and fungal pathogens. In: Karlovsky, P. (Ed.), Secondary Metabolites in Soil Ecology-Soil Biology 14. Springer-Verlag Berlin Heidelberg, Berlin, pp. 129-140.

Muse, R.R., Couch, H.B., Moore, L.D., and Muse, B.D. 1972. Pectinolytic and cellulolytic enzymes associated with Helminthosporium leaf spot on Kentucky bluegrass. Canadian J. Microbiol. 18(7): 1091-1098.

Pedrolli, D.B., Monteiro, A.C., Gomes, E., Carmona, E.C. 2009. Pectin and pectinases
Production, characterization and industrial application of microbial pectinolyticenzymes. Open Biotech. J. 3: 918.

Prade, R., Zhan, D., Ayoubi, P. and Mort, A. 1999. Pectins, pectinases and plant-microbe interactions. Biotech. Genet. Eng. Res. 16: 361-391.

Pushpavathi, Y., Dash, S.N., Mishra, M.K. and Triveni, V. 2015. Management of Fusarium wilt of banana under coastal Odisha conditions. Int. J . Farm Sci. 5(4): 241-247.

Reithner, B., Brunner, K., Schuhmacher, R., Peissl, I., Seidl, V., Krska, R. and Zeilinger, S. 2005. The G protein a subunit Tga1 of Trichoderma atrovirideis involved in chitinase formation and differential production of antifungal metabolites. Fungal Gen. Biol. 42: 749-760.

Rubio, M.B., Hermosa, R., Reino, J ., Collado, I.G. and Monte, E. 2009. Thctf1 transcription factor of Trichoderma harzianumis involved in 6-pentyl-2H-pyran-2-one production and antifungal activity. Fungal Gen. Biol. 46: 1727.

Shukla, A. and Dwivedi, S.K. 2012. Pathogenic action of $\mathrm{Cx}, \mathrm{PG}$, and PMG enzymes of Fusariumudum and Fusarium oxysporum $\mathrm{f}$. sp. ciceri. Int. J . Curr. Res. 4: 111-113.

Verlent, I., Vanloey, C.A., Smout, C., Duvetter, T. and Hendriclox, M.E. 2004.Purified tomato polygalacturonase activity during thermal and high-pressure treatment. Biotech. Bioeng. 86: 63-71.

Vincent, J.M. 1927. Distortion of fungal hyphae in the presence of certain inhibitors. Nature. 59: 850.

Waggoner, Paul, E. and Diamond, A.E. 1955. Production and role of extra cellular pectic enzymes of Fusarium oxysporum f.sp. lycopersici. Phytopath. 45: 79-87. 